\title{
Tick-borne pathogens, including Crimean-Congo haemorrhagic fever virus, at livestock markets and slaughterhouses in western Kenya
}

\author{
Tatenda Chiuya ${ }^{1,2}$, Daniel Masiga ${ }^{1}$, Laura Falzon ${ }^{3,4}$, Armanda Bastos ${ }^{2}$, Eric Fevre ${ }^{3,4}$, and \\ Jandouwe Villinger ${ }^{1}$ \\ ${ }^{1}$ International Centre of Insect Physiology and Ecology (icipe) \\ ${ }^{2}$ University of Pretoria \\ ${ }^{3}$ University of Liverpool \\ ${ }^{4}$ International Livestock Research Institute
}

July 30, 2020

\begin{abstract}
Vectors of emerging infectious diseases have expanded their distributional ranges in recent decades due to increased global travel, trade connectivity, and climate change. Transboundary range shifts, arising from the continuous movement of humans and livestock across borders, are of particular disease control concern. Several tick-borne diseases are known to circulate between eastern Uganda and the western counties of Kenya, with one fatal case of Crimean-Congo haemorrhagic fever (CCHF) reported in 2000 in Western Kenya. Recent reports of CCHF in Uganda have highlighted the risk of cross-border disease translocation and the importance of establishing inter-epidemic, early warning systems to detect possible outbreaks. We therefore carried out surveillance of tick-borne zoonotic pathogens at livestock markets and slaughterhouses in three counties of western Kenya that neighbour Uganda. Ticks and other ectoparasites were collected from livestock and identified using morphological keys. The two most frequently sampled tick species were Rhipicephalus decoloratus (35\%) and Amblyomma variegatum (30\%), and Ctenocephalides felis fleas and Haematopinus suis lice were also present. In total 486 ticks, lice, and fleas were screened for pathogen presence using established molecular workflows incorporating high-resolution melting analysis and identified through PCR-sequencing of PCR products. We detected CCHF virus in Rh. decoloratus and Rhipicephalus sp. cattle ticks and 82 of 96 pools of Am. variegatum were positive for Rickettsia africae. Apicomplexan protozoa and bcteria of veterinary importance, such as Theileria parva, Babesia bigemina, and Anaplasma marginale, were primarily detected in rhipicephaline ticks. Our findings show the presence of several pathogens of public health and veterinary importance in ticks from livestock at livestock markets and slaughterhouses in western Kenya. Confirmation of CCHF virus, a Nairovirus that causes haemorrhagic fever with a high case fatality rate in humans, highlights the risk of under-diagnosed zoonotic diseases and calls for continuous surveillance and the development of preventative measures.
\end{abstract}

Tick-borne pathogens, including Crimean-Congo haemorrhagic fever virus, at livestock markets and slaughterhouses in western Kenya

Running title: Zoonotic tick-borne pathogens in Kenya

Tatenda Chiuya ${ }^{1,2}$, Daniel K. Masiga ${ }^{1}$, Laura C. Falzon ${ }^{3,4}$, Armanda D.S. Bastos ${ }^{2}$, Eric M. Fèvre ${ }^{3,4}$, Jandouwe Villinger ${ }^{1 *}$

\section{Affiliations :}

1. International Centre of Insect Physiology and Ecology (icipe ), P.O Box 30772-00100, Nairobi, Kenya 
2. Department of Zoology and Entomology, University of Pretoria, Private Bag 20, Pretoria 0028, South Africa

3. University of Liverpool, Institute of Infection, Veterinary and Ecological Sciences, Leahurst Campus, Chester High Road, Neston, CH64 7TE, United Kingdom

4. International Livestock Research Institute, Old Naivasha Road, PO Box 30709, 00100 Nairobi, Kenya

${ }^{*}$ Corresponding author, jandouwe@icipe.org

\section{Summary}

Vectors of emerging infectious diseases have expanded their distributional ranges in recent decades due to increased global travel, trade connectivity, and climate change. Transboundary range shifts, arising from the continuous movement of humans and livestock across borders, are of particular disease control concern. Several tick-borne diseases are known to circulate between eastern Uganda and the western counties of Kenya, with one fatal case of Crimean-Congo haemorrhagic fever (CCHF) reported in 2000 in western Kenya. Recent reports of CCHF in Uganda have highlighted the risk of cross-border disease translocation and the importance of establishing inter-epidemic, early warning systems to detect possible outbreaks. We therefore carried out surveillance of tick-borne zoonotic pathogens at livestock markets and slaughterhouses in three counties of Western Kenya that neighbour Uganda. Ticks and other ectoparasites were collected from livestock and identified using morphological keys. The two most frequently sampled tick species were Rhipicephalus decoloratus (35\%) and Amblyomma variegatum (30\%), and Ctenocephalides felis fleas and Haematopinus suis lice were also present. In total 486 ticks, lice, and fleas were screened for pathogen presence using established molecular workflows incorporating high-resolution melting analysis and identified through PCR-sequencing of PCR products. We detected CCHF virus in Rh. decoloratus and Rhipicephalus sp. cattle ticks and 82 of 96 pools of Am. variegatum were positive for Rickettsia africae. Apicomplexan protozoa and bacteria of veterinary importance, such as Theileria parva, Babesia bigemina, and Anaplasma marginale, were primarily detected in rhipicephaline ticks. Our findings show the presence of several pathogens of public health and veterinary importance in ticks from livestock at livestock markets and slaughterhouses in estern Kenya. Confirmation of CCHF virus, a Nairovirus that causes haemorrhagic fever with a high case fatality rate in humans, highlights the risk of under-diagnosed zoonotic diseases and calls for continuous surveillance and the development of preventative measures.

Keywords: Emerging infectious disease, Zoonoses, Nairovirus, Rickettsia, Rhipicephalus, East Africa.

\section{Introduction}

Ticks are vectors of a range of viral, bacterial, and protozoal pathogens of economic and public health importance (de la Fuente et al., 2008). Babesiosis, theileriosis, and anaplasmosis cause major livestock production losses in Kenya (Franck et al., 2015; Gachohi et al., 2012; Latib et al., 1995; Norval et al., 1984), while rickettsiosis constitutes a serious emerging public health threat globally (Brown, 2016; Fournier et al., 2017; Jensenius et al., 2017; Maina et al., 2017; Ndip et al., 2004; Parola et al., 2013; Rutherford et al., 2004). In addition to Rickettsia, tick-borne bacteria such as Ehrlichia and Anaplasma, and protozoa such as Babesia have been shown to infect humans in the Americas and Europe (Doudier et al., 2010). Ticks also transmit nairoviruses, most of which cause a mild non-pathognomonic febrile illness in humans, but some, such as Crimean-Congo haemorrhagic fever (CCHF) and Dugbe viruses, can cause severe systemic illness and mortality, affirming the importance of ticks in the transmission of viral haemorrhagic fevers (Papa et al., 2017). In livestock, Nairobi sheep disease virus, also a Nairovirus, is a constant threat to sheep production in East Africa and the Horn of Africa (Baron, 2015).

While the vectorial capacity of ticks is established, the role of lice and fleas in the epidemiology of vectorborne zoonoses is rarely investigated. Flea-borne rickettsioses, such as murine typhus (Rickettsia typhi) and flea-borne spotted fever (Rickettsia felis), both endemic in East Africa, are transmitted by Xenopsylla cheopis and Ctenocephalides felis fleas, respectively. However, these Rickettsia spp. have been detected in several other flea species in addition to the chief vectors (Luce-fedrow et al., 2015). Louse infestations result in severe 
pruritic mange in livestock, leading to production losses (Hornok et al., 2010), and epidemic typhus, caused by Rickettsia prowazekii, in humans, especially in overcrowded and poor social settings (Raoult \& Roux, 1997).

With travel and trade thought to be major drivers of emerging pathogen spread (Kilpatrick, 2012), the movement of livestock and people among East African countries could enhance the circulation of emerging pathogens, especially given that high arboviral activity has been reported across the region (Mossel et al., 2017; Nyaruaba et al., 2019). Smallholder livestock production in East Africa is associated with livestock movement across provincial and national borders to livestock markets (LMs) in peri-urban areas (Fèvre et al., 2005) in which animals have been found to be heavily infested by ticks (Sang et al., 2006). Livestock movement plays a major role in the introduction of infective foci in naïve areas where they can then be disseminated by capable vectors (Fèvre et al., 2006). Livestock movements have been implicated in past and recent Rift Valley fever (RVF) outbreaks in Kenya (Baba et al. 2016; Munyua et al., 2010; WHO, 2018).

Outbreaks of CCHF (Dunster et al., 2002) and RVF (WHO, 2018) have been reported before in Western Kenya, and there is serological evidence of circulation of chikungunya, yellow fever, West Nile, and RVF viruses (Cook et al., 2017; Inziani et al., 2020; Mease et al., 2011; Nyaruaba et al., 2019). While reports on the occurrence of zoonotic vector-borne bacteria are scant, the high prevalence of malaria in western Kenya results in under-investigation of other causes of febrile illnesses. Ticks, fleas, and lice may be both vectors and reservoirs of most pathogens they transmit, making them an important component in the transmission dynamics of vector-borne zoonoses (Raoult \& Roux, 1997). Elsewhere in Kenya and East Africa, the occurrence of bacterial pathogens of zoonotic and veterinary potential in ticks and fleas has been reported. Tick and flea-borne spotted fever group (SFG) rickettsiosis agents (R. africae, Rickettsia conorii, Rickettsia aeschlimanii, $R$. felis, and Rickettsia asembonensis sp. nov.) have been detected elsewhere in Kenya (Maina et al., 2014, 2019; Mwamuye et al., 2017; Macaluso et al., 2003) and East Africa (Kumsa et al., 2015; Nakao et al., 2013; Nakayima et al., 2014). A broad spectrum of bacteria and protozoa of veterinary and public health importance have also been detected, including Theileria parva, Ehrlichia ruminantium, Ehrlichia chaffeensis, Anaplasma marginale, Anaplasma phagocytophilum, and Anaplasma platys (Oundo et al., 2020; Ringo et al., 2018; Omondi et al., 2017; Mwamuye et al., 2017; Teshale et al., 2015). Hyalomma, Amblyom$m a$, and Rhipicephalus ticks sampled from livestock in North-Eastern Kenya were previously shown to be infected with CCHF, Bunyamwera, Dugbe, Ndumu, Semliki forest, Thogoto, Ngari, Dhori, and West Nile viruses (Lwande et al., 2013; Sang et al., 2011, 2006). These viruses are endemic in East Africa (Nyaruaba et al., 2019) and some, such as Semliki Forest, Wesselsbron, Ngari, and Bunyamwera viruses, have only been isolated from mosquitoes (Ajamma et al., 2018; Villinger et al., 2017; Lwande et al., 2013). In most instances, ticks with arboviruses were collected from cattle at LMs and abattoirs, confirming the importance of these facilities for epidemiological investigations of these viruses.

Active surveillance for zoonotic pathogens and their vectors generates information on their presence and prevalence and can identify novel vector-pathogen associations. Such information can facilitate early detection and quantification of pathogen burdens and thus is important for planning control strategies to reduce spillover infection from livestock to humans. Most of the diseases are characterised by non-specific febrile illness, which can be easily confused with other fever-causing agents. Awareness of their presence improves clinical referral and diagnosis.

To investigate the risk posed by the movement of arthropod vector infested animals via LMs in the Lake Victoria basin of East Africa, we collected ticks, fleas, and lice from livestock at both LMs and slaughterhouses (SHs). We employed high-throughput molecular techniques coupled with Sanger sequencing to rapidly detect pathogens of zoonotic and veterinary importance in these arthropods.

\section{Materials and Methods}

\section{Study site}

The study was carried out in neighbouring counties, viz. Busia, Bungoma, and Kakamega, in Western Kenya. This region, part of which shares borders with Uganda, is representative of the larger Lake Victoria basin 
ecosystem and has the highest rural human and livestock population densities in East Africa. The predominant farming type is a mixed smallholder livestock production system, though husbandry practices are rapidly changing as production moves from largely subsistence to increasing intensification, with consequent impacts on disease emergence and transmission (Fèvre et al., 2017).

\section{Study design and sample collection}

The study design and sampling collection are described in detail elsewhere (Falzon et al., 2019). Briefly, four LMs and neighbouring SHs were selected in each county (Figure 1), where each LM was closely associated with a cattle or pig SH. At each LM, 10 animals (six cattle, three goats, and one sheep) were selected via systematic random sampling. We attempted to select six cattle, three goats, and one sheep during each visit, though the number of animals sampled did not always follow the above ratio as it was occasionally challenging to get consent from owners of small ruminants. Signed consent was sought from the animal owners or traders accompanying sampled animals, and a short questionnaire was administered to capture demographic and animal ownership details. Animals were then physically restrained and, after a general clinical examination, blood was drawn by a qualified veterinarian from the jugular vein using a vacutainer. Nasal swabs and faecal samples were also collected. Any external parasites present on the hide of the selected animals were removed with gloved hands and placed into falcon tubes containing $70 \%$ ethanol. At cattle and pig SHs, a similar procedure was followed. In addition to ticks, lice and fleas were collected if present on sampled animals. Sample bottles and blood tubes were barcoded and transported to the field lab in Busia in a cool box with ice packs. Arthropods were stored at $-40^{\circ} \mathrm{C}$ at the International Livestock Research Institute (ILRI) Department of Veterinary Services lab in Busia before being shipped on dry ice to the Martin Lüscher Emerging Infectious Diseases (ML-EID) laboratory at the International Centre of Insect Physiology and Ecology (icipe) where they were stored at $-80^{\circ} \mathrm{C}$.

\section{Morphological identification of ticks, lice, and fleas}

Ticks, lice, and fleas were morphologically identified to species level using a stereomicroscope (Zeiss, Oberkochen, Germany) with the aid of identification keys (Walker et al., 2004; Pratt, 1973). Excessively engorged tick samples were excluded from the analysis. Representative specimens were photographed using an Axiocam ERc 5s digital camera (Zeiss) mounted on a stereomicroscope. Ticks, lice, and fleas were pooled (1-3) according to developmental stage, sex, species, and host from which they were sampled.

\section{Nucleic acid extraction from arthropods and selected livestock blood samples}

Arthropod pools were homogenised before nucleic acid extraction. Each pool was placed in a 1.5-ml Eppendorf tube with pre-weighed scoops of $750 \mathrm{mg}$ of $2.0-\mathrm{mm}$ and $150 \mathrm{mg}$ of $0.1-\mathrm{mm}$ yttria stabilized zirconium oxide (zirconia/yttria) beads (Biospec, USA), in which they were mechanically disrupted using a Mini-Beadbeater16 (BioSpec, Bartlesville, OK) for 60-90 seconds. Phosphate buffered saline (PBS) (360 $\mu$ l) was added to each tube, vortexed, and $210 \mu \mathrm{l}$ of the resulting homogenate was transferred to a 96 -well specimen processing cartridge. DNA and RNA were extracted using a MagNA 96 DNA and Viral NA Small Volume Kit (Roche Applied Science, Penzberg, Germany) in a MagNA Pure 96 robot (Roche Molecular Systems, California, USA). A sindbis virus culture isolate was included as a positive extraction control and PBS was used as a negative extraction control in each run. Total nucleic acid was eluted in $50 \mu \mathrm{l}$ of RNAse-free water.

Animal blood samples associated with arthropod pools identified as positive for $R$. africae and CCHF virus were selected for pathogen screening. Nucleic acids from blood samples were extracted using the magnetic bead-based High Prep Viral DNA/RNA kit (MagBio Genomics, Gaithersburg, USA). First, $200 \mu$ l of blood was added to 1.5- $\mu$ l Eppendorf tubes containing $528 \mu \mathrm{l}$ of a lysis master-mix consisting of VDR lysis buffer, isopropanol, and carrier RNA, and vortexed. Then $10 \mu \mathrm{l}$ of proteinase K and $10 \mu \mathrm{l}$ of MAG-S1 magnetic beads were added and mixed into solution by inversion. The subsequent steps were performed according to the manufacturer's instructions.

\section{Molecular identification of ticks, lice, and fleas}

Molecular identification was performed on 15 single specimens for which morphologic identification to species 
level was equivocal. We amplified three target genes: the internal transcribed spacer-2 (ITS2), cytochrome oxidase 1 (CO1), and 16S ribosomal (r)RNA (Supplementary Table 1). The PCRs were performed in a SimpliAmp PCR Thermal Cycler (Applied Biosystems, Singapore) in 10- $\mu$ l reactions that consisted of $2 \mu l$ of $5 \mathrm{x}$ HOT FIREPol@ Blend Master Mix (Solis BioDyne, Estonia), $2 \mu \mathrm{l}$ of template, and $0.5 \mu \mathrm{l}$ of $10 \mu \mathrm{M}$ primer. Molecular grade water was included as a negative control on each run. The cycling conditions have been described before in detail (Mwamuye et al., 2017), with the exception that the final extension step for the three fragments was seven minutes. Amplicons of the correct size were visualised alongside QuickLoad@ 100-bp DNA Ladder (Biolabs, UK) by electrophoresis on $1.6 \%$ ethidium stained agarose gels under UV light. Bi-directional sequencing of amplicons purified by Exo 1-rSAP combination (Biolabs, UK) was performed by Macrogen (Netherlands). Sequence chromatograms were inspected, edited, and aligned using Geneious Prime version 2019.0.4 software (Biomatters, New Zealand). The resulting sequence contigs were used in nucleotide BLAST searches (Altschup et al., 1990) against the GenBank nr database (www.ncbi. nlm.nih.gov/blast) to identify sequence matches.

\section{Molecular detection of arboviral, bacterial, protozoan pathogens}

\section{Detection of arboviruses}

A previously described multiplex reverse transcription (RT)-PCR-HRM test was initially utilised for the detection of arboviruses within theFlavivirus, Alphavirus, Nairovirus, Phlebovirus, Orthobunyavirus, and Thogotovirus genera (Villinger et al., 2017) (Supplementary Table 1). This was preceded by cDNA synthesis using the High Capacity cDNA Reverse Transcription (RT) kit (Applied Biosystems, Lithuania) in a 20- $\mu$ l reaction mixture that contained $10 \mu \mathrm{l}$ nucleic acid extract, $1 \mathrm{U} / \mu \mathrm{l}$ RNase inhibitor, $100 \mathrm{Mm}$ dNTPs, $1 \mathrm{X}$ RT buffer, $2.5 \mathrm{u} / \mu \mathrm{l}$ reverse transcriptase enzyme and $40 \mathrm{u} / \mu \mathrm{l}$ non-ribosomal random hexa-nucleotide primers (Endoh et al., 2005). The reactions were performed in a SimpliAmp thermocycler (Applied Biosystems, Singapore) using previously described thermal cycling conditions (Ajamma et al., 2018). The 10- $\mu$ reaction mixture for the multiplex PCR-HRM contained $1 \mu \mathrm{l}$ cDNA template, $5 \mu \mathrm{l}$ of 2x MyTaq HS Mix (Bioline, UK) and $1 \mu \mathrm{l}$ of $50 \mu \mathrm{M}$ SYTO-9 (Life Technologies, USA). Multiplex PCR-HRM reactions were performed in a Rotor-Gene Q real-time PCR thermocycler (Qiagen, Hilden, Germany) using touchdown thermal cycling conditions described in detail elsewhere (Villinger et al., 2017). Each run included cDNA of the sindbis virus as a positive control and no-template extraction controls and molecular grade water as PCR negative controls. HRM profiles were visualised with Rotor-Gene Q Series software 2.1.0. All positive samples were separately re-run using primer mixes for each of alphaviruses, flaviviruses, and nairoviruses and the same conditions for the multiplex PCR-HRM runs (Villinger et al., 2017) (Supplementary Table 1). Amplicons from singleplex runs were purified with an Exo 1-rSAP combination (Biolabs, UK) and submitted for bidirectional sequencing to Macrogen (Netherlands). Larger fragments using a conventional PCR assay that targets the Nairovirus L-polymerase gene (Supplementary Table 1) were also amplified, purified, and sequenced as previously described (Honig et al., 2004).

\section{Detection of bacterial and protozoan pathogens}

Tick, louse, flea, and livestock-blood samples were also screened for bacteria and protozoa using a combination of PCR-HRM and conventional PCR. Previously developed primers that target the 16S rRNA gene of Anaplasma (Mwamuye et al., 2017), Ehrlichia (Mwamuye et al., 2017), and Rickettsia (Nijhof et al., 2007), as well as primers that target the $18 \mathrm{~S}$ ribosomal gene of Theileria andBabesia parasites (Georges et al., 2001), were used for initial screening (Supplementary Table 1). Ten-microliter reactions that consisted of $2 \mu$ lemplate, $2 \mu \mathrm{l}$ 5X HOT FIREPol (R) EvaGreen HRM Mix (Solis BioDyne, Estonia), and $0.5 \mu$ of each primer at $10 \mu \mathrm{M}$ concentrations. Cycling was carried out in a Rotor-Gene Q real-time PCR thermocycler (Qiagen, Hilden, Germany) as described before (Mwamuye et al., 2017). Positive controls for Anaplasma (A. marginale) andRickettsia (R. africae) (previously detected inicipe 's ML-EID lab from Amblyomma spp. ticks) were included in the runs. Resultant HRM profiles were visually inspected with Rotor-Gene Q Series software 2.1.0 and representative amplicons with unique HRM profiles were purified using an Exo 1-rSAP combination (Biolabs, UK) and sequenced at Macrogen (Netherlands). 
Positive Ehrlichia and Anaplasma samples were further amplified with a semi-nested PCR to generate a longer fragment of the $16 \mathrm{~S}$ rRNA gene $(1030 \mathrm{bp})$ by combining the Anaplasmataceae-specific forward primer, EHR16SD (Parola et al., 2001) with universal reverse primers pH1522 (Edwards et al., 1989) and pH1492 (Reysenbach et al., 1992) for first and second round amplification, respectively (Supplementary Table 1). Primary amplifications were performed using a hot-start activation step of $95^{\circ} \mathrm{C}$ for $15 \mathrm{~min}$ followed by 1 cycle of $95^{\circ} \mathrm{C}$ for $20 \mathrm{~s}, 63^{\circ} \mathrm{C}$ for $30 \mathrm{~s}$, and $72^{\circ} \mathrm{C}$ for $90 \mathrm{~s}, 2$ cycles of $95^{\circ} \mathrm{C}$ for $20 \mathrm{~s}, 62^{\circ} \mathrm{C}$ for $30 \mathrm{~s}$, and $72^{\circ} \mathrm{C}$ for 90 $\mathrm{s}, 2$ cycles of $95^{\circ} \mathrm{C}$ for $20 \mathrm{~s}, 61^{\circ} \mathrm{C}$ for $30 \mathrm{~s}$, and $72^{\circ} \mathrm{C}$ for $90 \mathrm{~s}$, followed with 35 cycles of $95^{\circ} \mathrm{C}$ for $20 \mathrm{~s}, 60^{\circ} \mathrm{C}$ for $30 \mathrm{~s}$, and $72^{\circ} \mathrm{C}$ for $80 \mathrm{~s}$, and a final extension at $72^{\circ} \mathrm{C}$ for $10 \mathrm{~min}$. The secondary $20-\mu \mathrm{l}$ amplification reactions utilised $2 \mu \mathrm{l}$ of PCR products from primary reactions as templates. The cycling profile consisted of: $95^{\circ} \mathrm{C}$ for $15 \mathrm{~min} ; 3$ cycles of $95^{\circ} \mathrm{C}$ for $20 \mathrm{~s}, 61^{\circ} \mathrm{C}$ for $30 \mathrm{~s}$, and $72^{\circ} \mathrm{C}$ for $90 \mathrm{~s} ; 37$ cycles of $95^{\circ} \mathrm{C}$ for $20 \mathrm{~s}, 60^{\circ} \mathrm{C}$ for $30 \mathrm{~s}$, and $72^{\circ} \mathrm{C}$ for $80 \mathrm{~s}$, and a final extension at $72^{\circ} \mathrm{C}$ for $10 \mathrm{~min}$. To minimise the risk of contamination we set up the second reaction in a PCR enclosure and opened only one tube at a time. Products were visualised after gel electrophoresis to confirm the presence of the expected product at 1030bp. For Rickettsia, all samples with positive HRM profiles were further amplified with Rick- ompB primers (Roux \& Raoult, 2000) targeting a 856-bp region of the outer membrane protein B gene of all Rickettsia species (Supplementary Table 1). Positive samples were prepared for sequencing using the QuickClean II Gel Extraction Kit (GenScript, New Jersey, USA) and submitted to Macrogen (Netherlands) for bidirectional sequencing.

\section{Phylogenetic analysis}

All sequences were edited and aligned using Geneious alignment in Geneious Prime version 2019.0.4 software (Biomatters, New Zealand). Homologous sequences of reference and sequence entries closely related with each of the individual sequences generated in this study were identified through BLAST nucleotide searches against the GenBank nr database (Altschup et al., 1990). Each of the datasets compiled in this manner were aligned and the terminal regions corresponding to the primer sequences were removed prior to phylogenetic analysis. Maximum likelihood phylogenies were inferred for each gene using PhyML version 3.0., employing the Akaike information criterion for automatic selection for appropriate model of evolution (Guindon et al., 2010). Trees were visualised and edited in Figtree 1.4 (Rambaut, 2014).

\section{Estimation of individual-level pathogen prevalences from pooled samples}

Individual-level prevalences of pathogens detected in pooled samples were estimated by a maximum likelihood approach in a frequentist model. True prevalence estimates within vector populations assumed $100 \%$ sensitivity and specificity of pooled-sample results and took into account the number of individuals in each pool tested (Cowling et al. 1999; Williams \& Moffitt, 2001). The computations were performed online using Epitools an epidemiological calculator accessed from https://epitools.ausvet.com.au/ppvariablepoolsize (Sergeant, 2009).

\section{Results}

\section{Vector collection and diversity at LMs and SHs}

A total of 456 ticks (434 adults and 22 nymphs), 28 lice (Haematopinus suis ), and two fleas (Ct.felis) collected from cattle, goats, sheep, and pigs at LMs and SHs were analysed in this study. Over $80 \%$ of the vectors collected at LMs and SHs came from cattle (Supplementary Table 2). This was partially due to the fact that $60 \%$ of the animals sampled at each of these locations were cattle, which were generally more tick-infested than goats, sheep, or pigs. The lice were primarily collected from pigs at SHs and the fleas were collected from cattle.

Representative specimens of Rhipicephalus evertsi (one adult), Rhipicephalus appendiculatus (one adult, one nymph),Amblyomma gemma (one adult), Amblyomma variegatum (one adult, one nymph), Haemaphysalis sp. (one adult), Rhipicephalus decoloratus (one adult), and Rhipicephalus spp. (six adults, one nymph), identified morphologically (Supplementary Figure 1), were selected for molecular tick identification (Table 1). Molecular identifications concurred with morphological identifications for $R h$. appendiculatus (T16), $R h$. decoloratus (T134), and Am. variegatum (T199). However, we resolved a tick specimen (T105) that we 
morphologically identified as $R h$. decoloratus to be $R h$. microplus based on its $16 \mathrm{~S}$ rRNA sequence homology. The ITS2 sequence of an Am. gemma (T222) had highest homology with Am. hebraeum, as there were no other Am. gemma ITS2 reference in the GenBank database. Seven out of nine specimens of Rhipicephalus, Haemaphysalis, and Amblyomma spp. that could not be identified to species level by morphology alone were identified based on sequence homologies of at least two of the markers. The most commonly sampled tick species were Rh. decoloratus (35\%) and Am. variegatum (30\%).

\section{Pathogens detected}

We detected Anaplasma and Rickettsia bacteria, Babesia, Theileria, Hepatozoon protozoa, and CCHF virus (Figure 2) in ticks and lice collected from $13 \mathrm{LMs}$ and $13 \mathrm{SHs}$ across the three sampled counties (Table 2 ). Out of the 333 pools tested (Supplementary Table 2), one Rh. decoloratus and one Rhipicephalus sp. were positive for CCHF virus (deposited GenBank accessions MN267048, MN267049) (0.62\% estimated true prevalence). These ticks were removed from cattle at two SHs. The CCHF virus isolates identified fall into the genotype II clade, which includes isolates from Uganda and the Democratic Republic of Congo (DRC) (Figure 3). Their nucleotide sequence identity was highest (98.6\%) to the Nakiwogo (GenBank accession KX013483) strain isolated from Uganda (Simpson et al., 1967).

Eighty-two out of 96 pools of Am. variegatum, three pools of Rh. decoloratus, four pools of Rhipicephalus sp., one pool of Rh. appendiculatus, one pool of Am. gemma, and one pool of H. suis were positive for R. africae (deposited GenBank accessions MN294740-MN294749) (Table 2). These $R$. africae-positive ectoparasites were removed from cattle, sheep, goats and pigs. Two of the $R$. africae sequences from this study were identical to those previously detected in Am. variegatum ticks in Asembo in Kenya (GenBank accession KF660534) and another to a strain detected in a patient diagnosed with African tick bite fever in Tanzania (unpublished; GenBank accession KU721071). Rickettsia africae variants in this study were characterised by base substitutions in several positions and possessed a four-base insertion that is absent from most Kenyan isolates (Supplementary Figure 2).

We detected A. platys (deposited GenBank accessions MN266939-MN266941) in five pools of Rh. decoloratus, two pools of Rhipicephalus sp., and three pools of Rh. appendiculatus, all obtained from cattle (Supplementary Table 3). Anaplasma marginale (deposited GenBank accessions MN266931-MN266935) was detected in four pools of Rh. decoloratus and two pools of Rhipicephalus sp. Anaplasma ovis (deposited GenBank accessions MN266936-MN266938) was detected in two pools of Rh. decoloratus, three pools of Rhipicephalus sp., and one pool of Rh. evertsi from goats and cattle.

Only one Rhipicephalus sp. tick pool was positive for T. parva (GenBank accession MN294730) (Table 2). Twelve out of 108 pools of Rh. decoloratus were positive for Theileria mutans (deposited GenBank accessions MN294725-MN294729), while two pools were positive for Theileria taurotragi (deposited GenBank accessions MN294731-MN294732). In Rhipicephalus sp., six pools were positive for T. mutans, three for T. taurotragi, and one for Theileria velifera (deposited GenBank accessions MN294733-MN294734). Theileria mutans was also detected in one Rh. appendiculatus and one A. variegatum pool. All Theileria spp. positive ticks were removed from cattle (Supplementary Table 3). We detected Babesia caballi (deposited GenBank accessions MN294721-MN294723) exclusively in eight $A m$. variegatum tick pools. Single pools each of $R h$. decoloratus, Rh. appendiculatus, and Am. variegatum were positive for Babesia bigemina (deposited GenBank accession MN294720). One pool of Rh. decoloratus was positive for Hepatozoon canis (deposited GenBank accession MN294724). The phylogenetic relationships of the apicomplexan parasite sequences identified in this study with homologous pathogen sequences are shown in Figure 4.

In addition to these pathogens, we detected Coxiella endosymbionts (deposited GenBank accessions MN262071-MN262076, MN266922-MN266928, MN266946-MN266948), which are phylogenetically close to, but distinct from, Coxiella burnetii, the pathogen responsible for $\mathrm{Q}$ fever, in all the genera of ticks except in Haemaphysalis. The Coxiella endosymbionts characterised in this study fell into the group B and C clades of previously detected tick Coxiella endosymbionts of ticks (Figure 5).

No DNA/RNA of the pathogens evaluated in this study was detected in the flea specimens. All of the 33 
selected associated livestock blood samples were negative for $R$. africae and CCHF virus. Thirty-one of these blood samples were from animals (28 cattle and three pigs) from which $R$. africae positive Am. variegatum ticks were collected, while the other two were from the cattle from which the two CCHF virus-positive Rhipicephalus spp. were obtained.

\section{Discussion}

\section{CCHF detection in ticks}

We detected CCHF virus in ticks removed from cattle destined for slaughter at two SHs. This is the first description of CCHF virus in Rh. decoloratus ticks in Kenya, with previous studies reporting detection only in Hyalomma ticks from the north-eastern region (Sang et al., 2011). This suggests that other tick species besides Hyalomma spp. may be supporting the local transmission of the virus. As the infected Rhipicephalus spp. ticks in this study were blood-fed and collected from livestock, we also tested the blood of the livestock from which they came from for CCHF virus, but they were negative. Association between infected ticks and seropositivity is common; however, ticks can also be found on seronegative animals and vice-versa (Spengler et al., 2016). Domestic animals, especially sheep, have been shown to be asymptomatic carriers of the virus (Spengler et al., 2016), acting as reservoirs of infection (via ticks) to humans, who suffer significant morbidity (Ergönül, 2006). While Hyalomma ticks are the natural vector and reservoir of CCHF virus, other tick genera such as Rhipicephalus, have been found infected with the virus (Fakoorziba et al., 2015; Hoogstraal, 1979). Rhipicephalus spp. have also transmitted CCHF virus in laboratory settings and have been implicated in the transmission of CCHF virus (Balinandi et al., 2018; Ergönül, 2006). Therefore, Rhipicephalus spp. ticks may support transmission of the virus in areas where Hyalomma spp. are absent. However, confirmation of this requires comprehensive competency studies, and an understanding of the landscape epidemiology of this virus and its transmission is in its early stages.

In Africa, there are three distinct clades of CCHF virus and the close phylogenetic relationship between our isolates and the Nakiwogo strain isolated in Uganda is not surprising (Ergönül, 2006; Lukashev et al., 2016) given the geographical proximity of our study site to Uganda and the extensive trade in live animals between the two countries. This finding supports the circulation of a single strain of virus between the two countries, which may be facilitated through cross-border movement of infected livestock. At-risk groups for CCHF virus infection include farmers, veterinarians, and abattoir and health-care workers (Cook et al., 2017; Ergönül, 2006). CCHF outbreaks have not been reported in Kenya since the year 2000 when a fatal case in Western Kenya showed the possibility of the virus circulating in the region. However, Lwande et al. (2012) found a $23 \%$ human seroprevalence of IgG antibodies to CCHF virus in North Eastern Kenya, Infection has been reported after skin contact with livestock, blood spatters during slaughtering, tick bites, and when health care workers take care of haemorrhaging patients (Ergönül, 2006). Our findings therefore highlight the potential for human exposure to CCHF virus at these and other LMs and SHs, and at public health facilities, and emphasise the need for routine surveillance for this pathogen and adopting a One Health approach. Other LM/SH-based surveillance studies in Kenya have described the occurrence of other arboviruses in ticks, which indicates the importance of ticks in their epidemiology (Lwande et al., 2013; Sang et al., 2011, 2006). While most of these studies targeted pastoralist regions, our findings demonstrate that the risk of human exposure to tick-borne arboviruses is also present in tropical small-holder systems in East Africa.

While Hyalomma spp. ticks are the chief vectors of CCHF virus, other species may also be important to transmission ecologies due to co-feeding transmission between infected and non-infected ticks, even in the absence of viraemia in the host. An infected tick may transmit a virus to a non-infected co-feeding tick without the host having detectable virus in its blood (Kazimírová et al., 2017). Such non-viraemic transmission is presumed to contribute to amplification of CCHF virus in nature because the virus can be transmitted among ticks even without detectable viraemia in the host (Bente et al., 2013).

\section{Rickettsia africae in ticks and lice}

We demonstrated a high prevalence (78.95\%; estimated true prevalence) of $R$. africae, the agent of African tick bite fever (ATBF, also known as African tick typhus) in humans, in Am. variegatum ticks collected 
mostly from cattle. Ever since the first description in Kenya of $R$. africae in Amblyomma ticks from the Maasai Mara region (Macaluso et al., 2003), high infection rates in Amblyomma ticks have been reported at SHs in Mombasa and Nairobi (Mutai et al., 2013), Siaya County, which borders Busia County (Maina et al., 2014), pastoral communities in North Eastern Kenya (Koka et al., 2017), the Shimba Hills National Reserve (Mwamuye et al., 2017), Baringo County (Omondi et al., 2017), and the Maasai Mara National Reserve (Oundo et al., 2020). Rickettsia africae has similarly been reported in Amblyomma ticks from Cameroon (Ndip et al., 2004), Zimbabwe (Beati et al., 1995), Senegal (Kelly et al., 2010), and the Central African Republic (CAR) (Dupont et al., 1995). We also detected $R$. africae at much lower prevalence in rhipicephaline ticks and for the first time we are aware of in $H$. suis lice. However, this novel finding is not surprising as lice are known vectors of other SFG rickettsiae (Hornok et al., 2010), but there is a paucity of studies that have surveyed rickettsiae in lice in Africa.

Our finding that all 34 livestock blood samples, from which the $R$. africae-positive ticks were obtained, were negative for the pathogen reinforces the notion that Amblyomma ticks are the major reservoir of the pathogen, but also indicates a low transmissibility to livestock. Since these ticks mostly parasitise large ruminants, it is evident that cattle play an important role in the epidemiology of ATBF by providing an abundant blood-meal source, as described previously for $R$. conorii by Kelly et al. (1991).

In travel medicine, ATBF, which is characterised by headaches, inoculation eschar, rash, and myalgia (Jensenius et al., 2003), is believed to be only second to malaria as the cause of febrile illness in travellers to sub-Saharan Africa (SSA). Most acute cases have been reported in tourists and foreign travellers with some fatal cases (Rutherford et al., 2004). Its seroprevalence is usually high in native populations, but few acute cases have been reported (Kelly et al., 1991; Ndip et al., 2004). This may be due to exposure at an early age leading to only mild clinical cases that are ignored, poor visibility of inoculation eschars on pigmented skin, and lack of diagnostic capacity at most health centres (Jensenius et al., 2003). Alternatively, some R. africae may be more virulent than others. In this study, we found $R$. africae variants that have been reported in previous studies (Kimita et al.,2016; Macaluso et al., 2003; Maina et al., 2014). The differences found in the nucleotide composition of the omp B gene, which codes for the most immuno-dominant surface cell antigen of Rickettsia, could possibly affect the virulence of $R$. africae variants. Surface cell antigens are involved in cellular adhesion of Rickettsia and subsequent entry into cells (Blanc et al., 2003). The hypothesis that variants with an intact $o m p$ B gene are less virulent than those with the deletion (Maina et al., 2014) may explain the absence of acute ATBF cases in Kenya, despite the high seroprevalence. This is supported by the evidence that genome reduction may lead to increased virulence in Rickettsia (Fournier et al., 2009). However, it remains to be seen if some of these variants can be detected in febrile patients in our study area. Clearly, there is a need for studies that focus on the public health aspect of this pathogen in endemic areas.

\section{Theileria, Babesia, and Anaplasma spp. in ticks}

We detected $A$. marginale, the cause of gall sickness, B. bigemina, which causes redwater, and T. parva, which causes East Coast fever in $1.88 \%, 0.63 \%$, and $0.31 \%$ (estimated true prevalences) of rhipicephaline ticks, respectively. These three diseases are major impediments to livestock production in Kenya and SSA, causing severe loss of production in affected animals (Wesonga et al., 2010; Woolhouse et al., 2015). We recently found T. parva more frequently in Rh. appendiculatus (15.7\% of tick pools) sampled in the Maasai Mara National Reserve, where no Babesia was detected (Oundo et al., 2020). The absence of T. parva in animal blood samples in this study may be partly explained by its biology, where most of its life cycle is found in the lymphoid system and only multiplies in RBC for completion of its life cycle (Mans et al., 2015). Accordingly, we found higher prevalence in ticks of the mildly pathogenic Theileria spp., T. taurotragi, T. velifera, and T. mutans than reported by Njiiri et al. (2015) in calves in Busia, Kenya, and by Lorusso et al. (2016) in Nigerian cattle. Nonetheless, these species can also cause theileriosis in immuno-compromised animals. We also detected Anaplasma platys, the cause of canine cyclic thrombocytopenia, in several pools of Rhipicephalus ticks from cattle. This pathogenic bacterium has been reported in other studies in ticks and blood from livestock (Omondi et al., 2017; Said et al., 2017; Lorusso et al., 2016) and recent evidence suggests that $A$. platys may infect humans, posing a risk in cases of opportunistic tick bites (Arraga-Alvarado et al., 
2014; Breitschwerdt et al., 2014; Maggi et al., 2013).

\section{Coxiella endosymbionts of ticks}

As in recent studies by Mwamuye et al. (2017) and Oundo et al. (2020), we also obtained Coxiella endosymbiont sequences from Rickettsia 16S rRNA primer amplicons. Previous studies have shown that these endosymbionts, which are closely related to the pathogen responsible for $\mathrm{Q}$ fever, C. burnetii, provide additional essential nutrients and reproductive fitness to ticks. Their elimination with antibiotic treatment was shown to negatively impact the fitness of the lone star tick Amblyomma americanum (Zhong et al., 2007). The phylogenetic co-divergence between the different tick species and their Coxiella endosymbionts shows the high specificity of these endosymbionts to their tick hosts. Four phylogenetic clades (A-D) have been described for tick-associated Coxiella endosymbionts. The sequences of endosymbionts from this study fell into groups B and C. Group B consists of Coxiella-endosymbionts of Amblyomma and Ornithodoros, while group C consists of rhipicephaline endosymbionts (Duron et al., 2015). These endosymbionts are nonpathogenic. However, it is important to note that there is evidence that Coxiella burnetii evolved recently from a maternally-inherited symbiont of ticks (Duron et al., 2015).

\section{Conclusions}

We identified an array of pathogens of both veterinary and public health importance in vectors collected from domestic animals at LMs and SHs. Significantly, the host animals were either being traded to destinations that were different from their origin or taken to slaughter, carrying infected vectors. These findings show how the animal trade can be the driver for new foci of infection in new areas, with risks to both domestic animal and human populations. Furthermore, their presence at SHs exposes abattoir workers, meat inspectors, butchers, and consumers to diseases like CCHF and ATBF. The zoonotic pathogens detected here cause febrile illness that can be clinically difficult to differentiate from malaria or other non-specific fevers (Crump et al., 2013). Indeed, a large majority of non-malarial febrile cases are never properly diagnosed. Therefore, evidence of their possible circulation and risk for human infection warrants their inclusion, if not routinely due to limitations in clinical differential diagnostics, at least in routine prospective surveys in health centres receiving febrile patients.

\section{Acknowledgements}

We gratefully acknowledge the Zoonoses in Livestock in Kenya (ZooLinK) team for collection of tick samples and Dr. Lillian Wambua (ZooLinK) for shipment of ticks to Nairobi from Busia and access to blood sample biobank and the database containing the metadata of the samples. We also acknowledge the technical contribution of Daniel O. Ouso for robotic total nucleic acid extraction, Kevin K. Ogola, Edwin K. Ogola, and the rest of the Martin Lüscher Emerging Infectious Diseases (ML-EID) laboratory team, to this work. We also acknowledge Bester Mudereri of icipe GIS and Remote Sensing unit for assistance in producing the study site map. This study received financial support from following organizations and agencies: The ZooLinK project was supported by the Biotechnology and Biological Sciences Research Council, the Department for International Development, the Economic \& Social Research Council, the Medical Research Council, the Natural Environment Research Council and the Defence Science \& Technology Laboratory, under the Zoonoses and Emerging Livestock Systems (ZELS) programme, grant reference BB/L019019/1. It also received support from the CGIAR Research Program on Agriculture for Nutrition and Health (A4NH), led by the International Food Policy Research Institute (IFPRI). We also acknowledge the CGIAR Fund Donors (http://www.cgiar.org/funders/); the study also received support from the European Union's Integrated Biological Control Applied Research Program (EU-IBCARP) (grant number: DCI-FOOD/2014/346-739) andicipe institutional funding from UK's Department for International Development (DFID); Swedish International Development Cooperation Agency (Sida); the Swiss Agency for Development and Cooperation (SDC); Federal Democratic Republic of Ethiopia; and the Kenyan Government. Tatenda Chiuya was supported by a German Academic Exchange Service (DAAD) through the icipe ARPPIS-DAAD scholarship and through a UP postgraduate bursary. The funders had no role in the design, data collection, interpretation, or decision to submit this publication. 


\section{Ethics statement}

The authors confirm that the ethical policies of the journal, as noted on the journal's author guidelines page, have been adhered to and the appropriate ethical review committee approval has been received. This study was nested within the Zoonoses in Livestock in Kenya (ZooLinK) project. Tick, louse, flea, and blood samples were collected from cattle, goats, sheep, and pigs at LMs or presented for slaughter at SHs and approved by the International Livestock Research Institute Institutional Animal Care and Use Committee (ref IACUC-RC 2017-04). Data from human owners of livestock was collected after approval by the International Livestock Research Institute (ILRI) Institutional Research Ethics Committee (ref ILRI-IREC 2017-08/2). Both committees are licensed by the National Commission for Science, Technology and Innovation (NACOSTI) in Kenya.

\section{Conflicts of interest}

The authors declare that they have no competing interests.

\section{Data availability statement}

All nucleotide sequence data generated in the study were deposited into the GenBank database under the following accessions: arthropod 16S: MN264214, MN264523-MN264525, MN266911-MN266916, MN266929, MN266930, MN266945; arthropod ITS2: MN266918, MN266919, MN266921, MN266944, MN266949MN266953, MN401349-MN401351; arthropod CO1: MN294735-MN294739, CCHF: MN267048, MN267049; Rickettsia spp.: MN294740-MN294749, MN266939-MN266941; Anaplasma spp.: MN266931-MN266941; Theileria spp.: MN294725-MN294734; Babesia spp.: MN294720-MN294723; Hepatozoon canis: MN294724; Coxiella spp.: MN262071-MN262076; MN266922-MN266928, MN266946-MN266948.

\section{Author contributions}

TC, DKM, LCF, EMF, and JV, designed the study and sampling. TC did the identification and laboratory work. TC and JV analysed the results. TC wrote the original manuscript while DM, DKM, LCF, ADSB, EMF, and JV edited and reviewed the manuscript. All the authors approved the final manuscript.

\section{References}

Ajamma, Y. U., Onchuru, T. O., Ouso, D. O., Omondi, D., Masiga, D. K., \& Villinger, J. (2018). Vertical transmission of naturally occurring Bunyamwera and insect-specific flavivirus infections in mosquitoes from islands and mainland shores of Lakes Victoria and Baringo in Kenya. PLoS Neglected Tropical Diseases, 12(11), e0006949. doi:10.1371/journal.pntd.0006949.

Altschul, S. F., Gish, W., Miller, W., Myers, E.W., \& Lipman D.J. (1990). Basic Local Alignment Search Tool. Journal of Molecular Biology, 215, 403-410. doi:10.1016/S0022-2836(05)80360-2

Arraga-alvarado, C. M., Qurollo, B. A., Parra, O. C., Berrueta, M. A., Hegarty, B. C., \& Breitschwerdt, E. B. (2014). Case report: Molecular evidence of Anaplasma platys infection in two women from Venezuela. American Journal of Tropical Medicine and Hygiene, 91, 1161-1165. doi:10.4269/ajtmh.14-0372.

Baba, M., Masiga, D. K., Sang, R., \& Villinger, J. (2016). Has Rift Valley fever virus evolved with increasing severity in human populations in East Africa? Emerging Microbes and Infections, 5(6), e58. doi:10.1038/emi.2016.57

Balinandi, S., Patel, K., Ojwang, J., Kyondo, J., Mulei, S., Tumusiime, A... Shoemaker, T.R (2018). Investigation of an isolated case of human Crimean-Congo hemorrhagic fever in Central Uganda. International Journal of Infectious Diseases, 68, 88-93. doi:10.1016/j.ijid.2018.01.013

Baron, M. D., \& Holzer, B. (2015). Nairobi sheep disease virus/Ganjam virus. Scientific and Technical Review of the Office International des Epizooties, 34, 411-417. doi:10.20506/rst.34.2.2367

Beati, L., Kelly, P. J., Matthewman, L. A., Mason, P. R., \& Raoult, D. (1995). Prevalence of Rickettsia -like organisms and spotted fever group rickettsiae in ticks (Acari: Ixodidae) from Zimbabwe. Journal of Medical 
Entomology, 32, 787-792. doi:10.1093/jmedent/32.6.787

Ben Said, M., Belkahia, H., El Mabrouk, N., Saidani, M., Alberti, A., Zobba, R...Messadi L (2017). Anaplasma platys -like strains in ruminants from Tunisia. Infection, Genetics and Evolution, 49, 226-233. doi:10.1016/j.meegid.2017.01.023

Bente, D. A., Forester, N. L., Watts, D. M., Mcauley, A. J., Whitehouse, C. A., \& Bray, M. (2013). CrimeanCongo hemorrhagic fever: history, epidemiology, pathogenesis, clinical syndrome and genetic diversity. Antiviral Research, 100(1), 159-89. doi:10.1016/j.antiviral.2013.07.006

Blanc, G., Ngwamidiba, M., Ogata, H., Fournier, P., Claverie, J., \& Raoult, D. (2003). Molecular evolution of Rickettsia aurface antigens: Evidence of positive selection. Molecular Biology and Evolution, 22,(10), 2073-2083. doi:10.1093/molbev/msi199

Breitschwerdt, E. B., Hegarty, B. C., Qurollo, B. A., Saito, T. B., Maggi, R. G., \& Blanton, L. S. (2014). Intravascular persistence of Anaplasma platys, Ehrlichia chaffeensis, andEhrlichia ewingii DNA in the blood of a dog and two family members. Parasites \& Vectors, 7, 298. doi:10.1186/1756-3305-7-298

Brown, L. D., \& Macaluso, K. R. (2016). Rickettsia felis , an emerging flea-borne rickettsiosis. Current Tropical Medicine Reports, 3, 27-39. doi:10.1007/s40475-016-0070-6

Cook, E.A.J., Grossi-soyster, E. N., De Glanville, W. A., Thomas, L. F., Kariuki, S., Bronsvoort, B.M... Fevre, E.M. (2017). The sero-epidemiology of Rift Valley fever in people in the Lake Victoria Basin of western Kenya. PLoS Neglected Tropical Diseases, 11(7), e0005731. doi:10.1371/journal.pntd.0005731

Cook, E. A. J., De Glanville, W. A., Thomas, L. F., Kariuki, S., Bronsvoort, B. M. de C., \& Fèvre, E. M. (2017). Working conditions and public health risks in slaughterhouses in western Kenya. BMC Public Health, 17(1), 1-12. doi:10.1186/s12889-016-3923-y

Cowling, D. W., Gardner, I. A., \& Johnson, W. O. (1999). Comparison of methods for estimation of individual-level prevalence based on pooled samples. Preventive Veterinary Medicine, 39(3), 211225. doi:10.1016/s0167-5877(98)00131-7

Crump, J. A., Morrissey, A. B., Nicholson, W. L., Massung, R. F., Stoddard, R. A., Galloway, R. L. . Bartlett, J.A.(2013). Etiology of severe non-malaria febrile illness in northern Tanzania: A prospective cohort study. PLoS Neglected Tropical Diseases, 7(7), e2324. doi:10.1371/journal.pntd.0002324

de la Fuente, J., Kocan, K. M., Almazán, C., \& Blouin, E. F. (2008). Targeting the tick-pathogen interface for novel control strategies. Frontiers in Bioscience, 1, 6947-6956. doi:10.1093/cid/cir155

Doudier, B., Olano, J., Parola, P., \& Brouqui, P. (2010). Factors contributing to emergence of Ehrlichia and Anaplasma spp . as human pathogens. Veterinary Parasitology, 167, 149154. doi:10.1016/j.vetpar.2009.09.016

Dunster, L., Dunster, M., Ofula, V., Beti, D., Kazooba-Voskamp, F., Burt, F., .. DeCock, K. M. (2002). First documentation of human Crimean-Congo hemorrhagic fever, Kenya. Emerging Infectious Diseases, 8(9), 1005-1006. doi:10.3201/eid0809.010510

Dupont, H. T., Brouqui, P., Faugere, B., \& Raoult, D. (1995). Prevalence of antibodies to Coxiella burnetii , Rickettsia conorii, and Rickettsia typhi in seven African countries. Clinical Infectious Diseases, 21, 1126 33. doi:10.1093/clinids/21.5.1126

Duron, O., Noël, V., Mccoy, K. D., Bonazzi, M., Sidi-Boumedine, K., Morel, O... Chevillon, C. (2015). The recent evolution of a maternally-inherited endosymbiont of ticks led to the emergence of the $\mathrm{Q}$ fever pathogen, Coxiella burnetii . PLoS Pathogens, 11, 1-23. doi:10.1371/journal.ppat.1004892

Edwards, E., Rogall, T., Blocker, H., Emde, M. \& Bottger, E.C. (1989).Isolation and direct complete nucleotide determination of entire genes. Characterization of a gene coding for $16 \mathrm{~S}$ ribosomal RNA. Nucleic Acids Research, 17, 7843-7853. doi:10.1093/nar/17.19.7843 
Endoh, D., Mizutani, T., Kirisawa, R., Maki, Y., Saito, H., Kon, Y., Morikawa, S., \& Hayashi, M. (2005). Species-independent detection of RNA virus by representational difference analysis using non-ribosomal hexanucleotides for reverse transcription. Nucleic Acids Research, 33(6), e65. doi:10.1093/nar/gni064

Ergönül, Ö. (2006). Crimean-Congo haemorrhagic fever. Lancet Infectious Diseases, 6, 203214. doi:10.1016/S1473-3099(06)70435-2

Fakoorziba, M. R., Naddaf-Sani, A. A., Moemenbellah-Fard, M. D., Azizi, K., Ahmadnia, S., \& Chinikar, S. (2015). First phylogenetic analysis of a Crimean-Congo hemorrhagic fever virus genome in naturally infected Rhipicephalus appendiculatus ticks (Acari: Ixodidae). Archives of Virology, 160(5), 1197-1209. doi:10.1007/s00705-015-2379-1

Falzon, L. C., Alumasa, L., Amanya, F., Kang, E., Kariuki, S., Momanyi, K... Fèvre, E.M. (2019). One Health in action: Operational aspects of an integrated surveillance system for zoonoses in Western Kenya. Frontiers in Veterinary Science, 6, 1-13. doi:10.3389/fvets.2019.00252

Fèvre, E. M., Picozzi, K., Fyfe, J., Waiswa, C., Odiit, M., Coleman, P. G., \& Welburn, S. C. (2005). A burgeoning epidemic of sleeping sickness in Uganda. Lancet, 366(9487), 745-747. doi:10.1016/S01406736(05)67179-6

Fèvre, Eric M., Bronsvoort, B. M. D. C., Hamilton, K. A., \& Cleaveland, S. (2006). Animal movements and the spread of infectious diseases. Trends in Microbiology, 14(3), 125-131. doi:10.1016/j.tim.2006.01.004

Fournier, P. E., El Karkouri, K., Leroy, Q., Robert, C., Giumelli, B., Renesto, P... Raoult, D. (2009). Analysis of the Rickettsia africae genome reveals that virulence acquisition in Rickettsia species may be explained by genome reduction. BMC Genomics, 10, 1-15.doi :10.1186/1471-2164-10-166

Fournier, P., Roux, V., Caumes, E., Donzel, M., \& Raoult, D. (2017). Outbreak of Rickettsia africae infections in participants of an adventure race in South Africa. Clinical Infectious Diseases, 27, 31623. doi:10.1086/514664

Franck, P., Moumouni, A., Aboge, G. O., Terkawi, M. A., Masatani, T., Cao, S...Xuan, X. (2015). Molecular detection and characterization of Babesia bovis , Babesia bigemina, Theileriaspecies and Anaplasma marginale isolated from cattle in Kenya. Parasites \& Vectors, 8, 496. doi:10.1186/s13071-015-1106-9

Gachohi, J., Skilton, R., Hansen, F., Ngumi, P., \& Kitala, P. (2012). Epidemiology of East Coast fever (Theileria parva infection) in Kenya : past , present and the future, Parasites \& Vectors, 5, 194. doi:10.1186/17563305-5-194

Georges, K., Loria, G. R., Riili, S., Greco, A., Caracappa, S., Jongejan, F., \& Sparagano, O. (2001). Detection of haemoparasites in cattle by reverse line blot hybridisation with a note on the distribution of ticks in Sicily.Veterinary Parasitology, 99, 273-286. doi:10.1016/s0304-4017(01)00488-5

Guindon S., Dufayard J.F., Lefort V., Anisimova M., Hordijk W., Gascuel O., (2010). "New Algorithms and methods to estimate maximum-likelihood phylogenies: Assessing the performance of PhyML 3.0." Systematic Biology, 59, 307-21. doi:10.1093/sysbio/syq010

Honig, J. E., Osborne, J. C., \& Nichol, S. T. (2004). The high genetic variation of viruses of the genus Nairovirus reflects the diversity of their predominant tick hosts. Virology, 318, 1016. doi:10.1016/j.virol.2003.09.021

Hoogstraal, H. (1979). The epidemiology of tick-borne Crimean-Congo Hemorrhagic fever in Asia, Europe, and Africa. Journal of Medical Entomology, 15 (4), 307-417

Hornok, S., Hofmann-Lehmann, R., de Mera, I. G., Meli, M. L., Elek, V., Hajtos, I., Repasi, A., Gonczi, E., Tanczos, B., Farkas, R., Lutz, H., \& de la Fuente, J. (2010). Survey on blood-sucking lice (Phthiraptera: Anoplura) of ruminants and pigs with molecular detection of Anaplasma and Rickettsia spp. Veterinary Parasitology, 174(3-4), 355-358. doi:10.1016/j.vetpar.2010.09.003 
Inziani, M., Adungo, F., Awando, J., Kihoro, R., Inoue, S., Morita, K., .. Mwau, M. (2020). Seroprevalence of yellow fever, dengue, West Nile and chikungunya viruses in children in Teso South Sub-County, Western Kenya. International Journal of Infectious Diseases, 91, 104-110. doi:10.1016/j.ijid.2019.11.004

Jensenius, M., Fournier, P., Kelly, P., Myrvang, B., \& Raoult, D. (2003). African tick bite fever. The Lancet, 3, 557-564. doi:10.1016/s1473-3099(03)00739-4

Jensenius, M., Fournier, P., \& Raoult, D. (2017). Rickettsioses and the international traveler. Clinical Infectious Diseases, 39, 1493-1499. doi:10.1016/j.ijid.2003.06.004

Kazimirova, M., Thangamani, S., \& Bartikova, P. (2017). Tick-borne viruses and biological processes at the tick-host-virus interface. Frontiers in Cellular and Infection Microbiology, 73, 39. doi:10.3389/fcimb.2017.00339

Kelly, P. J., Lucas, H., Eremeeva, M. E., Dirks, K. G., Rolain, J. M., Yowell, C...Raoult, D. (2010). Rickettsia africae, Western Africa. Emerging Infectious Diseases, 16(3), 571-573. doi:10.3201/eid1603.090346

Kelly, P. J., Raoult, J. D., \& Mason, P. R. (1991). Isolation of spotted fever group Rickettsia from triturated ticks using a modification of the centrifugation-shell vial technique. Transactions of the Royal Society of Tropical medicine and Hygiene, 85, 397-398. doi:10.1016/0035-9203(91)90303-g

Kilpatrick, A. M., \& Randolph, S. E. (2012). Drivers, dynamics, and control of emerging vector-borne zoonotic diseases. The Lancet, 380, 1946-1955. doi:10.1016/S0140-6736(12)61151-9

Kimita, G., Mutai, B., Nyanjom, S. G., Wamunyokoli, F., \& Waitumbi, J. (2016). Phylogenetic variants of Rickettsia africae, and incidental identification of "Candidatus Rickettsia moyalensis" in Kenya. PLoS Neglected Tropical Diseases, 10, 1-14. doi:10.1371/journal.pntd.0004788

Koka, H., Sang, R., Kutima, H. L., Musila, L., \& Macaluso, K. (2017). The detection of spotted fever group Rickettsia DNA in tick samples from pastoral communities in Kenya. Journal of Medical Entomology, 54, 774-780. doi:10.1093/jme/tjw238

Kumsa, B., Socolovschi, C., Raoult, D., \& Parola, P. (2015). Spotted fever group rickettsiae in ixodid ticks in oromia, ethiopia. Ticks and Tick-Borne Diseases, 6(1), 8-15. doi:10.1016/j.ttbdis.2014.08.001

Latib, A. A., Rowlandsbj, G. J., Punyuaa, D. K., \& Hassana, S. M. (1995). An epidemiological study of tick-borne diseases and their effects on productivity of zebu cattle under traditional management on Rusinga Island, western Kenya. Preventive Veterinary Medicine, 22, 169-181. doi:10.1016/0167-5877(94)00408-B

Lorusso, V., Wijnveld, M., Majekodunmi, A. O., Dongkum, C., Fajinmi, A., Dogo, A. G...Picozzi1, K. (2016). Tick-borne pathogens of zoonotic and veterinary importance in Nigerian cattle. Parasites \& Vectors, 9, 217. doi:10.1186/s13071-016-1504-7.

Luce-fedrow, A., Maina, A. N., Otiang, E., Ade, F., Omulo, S., \& Ogola, E. (2015). Isolation of Candidatus Rickettsia asemboensis fromCtenocephalides fleas. International Journal of Systematic and Evolutionary Microbiology, 66, 4512-4517. doi:10.1089/vbz.2014.1744

Lukashev, A. N., Klimentov, A. S., Smirnova, S. E., Dzagurova, K., Drexler, J. F., \& Gmyl, A. P. (2016). Phylogeography of Crimean Congo Hemorrhagic fever virus. PLoS ONE, 11, 114. doi:10.1371/journal.pone.0166744

Lutomiah, J., Musila, L., Makio, A., Ochieng, C., Koka, H., Chepkorir, E...Sang, R. (2014). Ticks and tick-borne viruses from livestock hosts in arid and semiarid regions of the eastern and northeastern parts of Kenya. Journal of Medical Entomology, 51, 269-277. doi:10.1603/ME13039

Lwande, O.W., Irura, Z., Tigoi, C., Chepkorir, E., Orindi, B., Musila, L., Venter, M., Fischer, A., Sang, R. (2012). Seroprevalence of Crimean Congo hemorrhagic fever virus in Ijara District, Kenya. Vector-Borne and Zoonotic Diseases, 12, 727-432. doi:10.1089/vbz.2011.0914 
Lwande, O. W., Lutomiah, J., Obanda, V., Gakuya, F., Mutisya, J., Mulwa... Sang, R. (2013) Isolation of tick and mosquito-borne arboviruses from ticks sampled from livestock and wild animal hosts in Ijara District, Kenya. Vector-Borne and Zoonotic Diseases, 13, 637-642. doi:10.1089/vbz.2012.1190

Macaluso, K. R., Davis, J. O. N., Alam, U., Korman, A. M. Y., Rutherford, J. S., Rosenberg, R., \& Azad, A. F. (2003). Spotted fever group rickettsiae in ticks from the Masai Mara region of Kenya. American Journal of Tropical Medicine and Hygiene, 68, 551-553. doi:10.4269/ajtmh.2003.68.551

Maggi, R. G., Mascarelli, P. E., Havenga, L. N., Naidoo, V., \& Breitschwerdt, E. B. (2013). Co-infection with Anaplasmaplatys, Bartonella henselae and CandidatusMycoplasma haematoparvum in a veterinarian. Parasites \& Vectors, 6, 103. doi:10.1186/1756-3305-6-103

Maina, A. N., Jiang, J., Omulo, S. A., Cutler, S. J., Ade, F., Ogola, E...Richards, A. (2014). High prevalence of Rickettsiaafricae variants in Amblyomma variegatum ticks from domestic mammals in rural Western Kenya: implications for human health. Vector-Borne and Zoonotic Diseases, 14, 693702. doi:10.1089/vbz.2014.1578.

Maina, A. N., Klein, T. A., Kim, H., Chong, S., Yang, Y., Mullins, K...Richards, A. (2017). Molecular characterization of novel mosquito-borne Rickettsia spp. from mosquitoes collected at the Demilitarized Zone of the Republic of Korea. PLoS ONE, 12(11), e0188327. doi:10.1371/journal.pone.0188327

Maina, A. N., Luce-fedrow, A., Omulo, S., Hang, J., Chan, T., Ade, F...Richards, A. (2019). Isolation and characterization of a novelRickettsia species (Rickettsia asembonensis sp. nov.) obtained from cat fleas (Ctenocephalides felis ). International Journal of Systematic and Evolutionary Microbiology 66, 4512-4517. doi:10.1099/ijsem.0.001382.

Mans, B. J., Pienaar, R., \& Latif, A. A. (2015). A review of Theileria diagnostics and epidemiology. International Journal for Parasitology: Parasites and Wildlife, 4(1), 104-118. doi:10.1016/j.ijppaw.2014.12.006

Mease, L. E., Coldren, R. L., Musila, L. A., Prosser, T., Ogolla, F., Ofula, V. O... Adungo, A. (2011). Seroprevalence and distribution of arboviral infections among rural Kenyan adults: A cross-sectional study. Virology Journal, 8, 371. doi:10.1186/1743-422X-8-371.

Mossel, E. C., Crabtree, M. B., Mutebi, J., Lutwama, J. J., Erin, M., Powers, A. M., \& Miller, B. R. (2017). Arboviruses isolated from mosquitoes collected in Uganda, 2008-2012. Journal of Medical Entomology, 54, 1403-1409. doi:10.1093/jme/tjx120

Munyua, P., Murithi, R. M., Wainwright, S., Githinji, J., Hightower, A., Mutonga, D. . Njenga, M.K. (2010). Rift Valley fever outbreak in livestock in Kenya, 2006 - 2007. American Journal of Tropical Medicine and Hygiene, 83, 58-64. doi:10.4269/ajtmh.2010.09-0292

Mutai, B. K., Wainaina, J. M., Magiri, C. G., Nganga, J. K., Ithondeka, P. M., Njagi, O. N... Waitumbi, J.N. (2013). Zoonotic surveillance for rickettsiae in domestic animals in Kenya. Vector-Borne and Zoonotic Diseases, 13, 360-366. doi:10.1089/vbz.2012.0977

Mwamuye, M. M., Kariuki, E., Omondi, D., Kabii, J., Odongo, D., Masiga, D., \& Villinger, J. (2017). Novel Rickettsia and emergent tick-borne pathogens: A molecular survey of ticks and tickborne pathogens in Shimba Hills National Reserve, Kenya. Ticks and Tick-borne Diseases, 8, 208-218. doi:10.1016/j.ttbdis.2016.09.002

Nabeth, P., Cheikh, D. O., Lo, B., Faye, O., Ould, I., \& Vall, M. (2004). Crimean-Congo hemorrhagic fever, Mauritania. Emerging Infectious Diseases, 10, 2143-2149. doi:10.3201/eid1012.040535

Nakao, R., Qiu, Y., Igarashi, M., Magona, J. W., Zhou, L., Ito, K., \& Sugimoto, C. (2013). High prevalence of spotted fever group rickettsiae in Amblyomma variegatum from Uganda and their identification using sizes of intergenic spacers. Ticks and Tick-Borne Diseases, 4(6), 506-512. doi:10.1016/j.ttbdis.2013.07.001 
Nakayima, J., Magona, J. W., \& Sugimoto, C. (2014). Molecular detection of tick-borne pathogens in ticks from Uganda. Research, 1:767. doi:10.13070/rs.en.1.767

Ndip, L. M., Bouyer, D. H., Travassos, A. P. A., Rosa, D., Titanji, V. P. K., Tesh, R. B., \& Walker, D. H. (2004). Acute spotted fever rickettsiosis among febrile patients, Cameroon. Emerging Infectious Diseases, 10, 3-8. doi:10.3201/eid1003.020713

Ndip, L. M., Fokam, E. B., Bouyer, D. H., Ndip, R. N., \& Titanji, V. P. K. (2004). Detection of Rickettsia africae in patients and ticks along the coastal region of Cameroon. American Journal of Tropical Medicine and Hygiene, 71, 363-366.

Nijhof, A. R. D. M., Bodaan, C., Postigo, M., Nieuwenhuijs, H., Opsteegh, M., Franssen, L...Jongejan, F.(2007). Ticks and Associated Pathogens Collected from Domestic Animals in the Netherlands. VectorBorne and Zoonotic Diseases, 7(4), 585-95. doi:10.1089/vbz.2007.0130

Njiiri, N. E., Bronsvoort, B. M. de C., Collins, N. E., Steyn, H. C., Troskie, M., Vorster, I... Toye, P.(2015). The epidemiology of tick-borne haemoparasites as determined by the reverse line blot hybridization assay in an intensively studied cohort of calves in western Kenya. Veterinary Parasitology, 210, 6976. doi:10.1016/j.vetpar.2015.02.020

Norval, R. A. I., Fivaz, B. H., Lawrence, J. A., \& Brown, A. F. (1984). Epidemiology of tick-borne diseases of cattle in Zimbabwe. Tropical Animal Health and Production, 16, 63-70. doi:10.1007/bf02239846

Nyaruaba, R., Mwaliko, C., Mwau, M., Mousa, S., \& Wei, H. (2019). Arboviruses in the East African Community partner states: a review of medically important mosquito-borne Arboviruses. Pathogens and Global Health, 113(5), 209-228. doi:10.1080/20477724.2019.1678939

Omondi, D., Masiga, D.K., Fielding, B.C., Kariuki, E., Ajamma, Y.U., Mwamuye, M.M., Ouso, D.O. \& Villinger, J. (2017). Molecular detection of tick-borne pathogen diversities in ticks from livestock and reptiles along the shores and adjacent islands of Lake Victoria and Lake Baringo, Kenya. Frontiers in Veterinary Science, 4, 73. doi:10.3389/fvets.2017.00073

Oundo, J.W., Villinger, J., Jeneby, M., Ong'amo, G., Otiende M.Y., Makhulu, E.E., Musa, A.A., Ouso, D.O., \& Wambua, L. (2020). Pathogens, endosymbionts, and blood-meal sources of host-seeking ticks in the fast-changing Maasai Mara wildlife ecosystem. PLOS ONE, in press. (bioRxiv preprint doi:10.1101/2020.01.15.907568)

Papa, A., Tsergouli, K., Tsioka, K., \& Mirazimi, A. (2017). Crimean-Congo hemorrhagic fever: Tick-hostvirus interactions. Frontiers in Cellular and Infection Microbiology, 7, 213. doi:10.3389/fcimb.2017.00213

Parola, P., Inokuma, H., Camicas, J., Brouqui, P., \& Raoult, D. (2001). Detection and identification of spotted fever group rickettsiae and ehrlichiae in African ticks. Emerging Infectious Diseases, 7(6), 10147. doi: 10.3201/eid0706.010616

Parola, P., Paddock, C. D., Socolovschi, C., Labruna, M. B., Mediannikov, O., \& Kernif, T. (2013). Update on tick-borne rickettsioses around the world: a geographic approach. Clinical Microbiology Reviews, 26, 657-702. doi:10.1128/CMR.00032-13

Pratt, H. D \& Wiseman, J.S. (1962) Fleas of public health importance and their control: Training guide insect control series. Public Health Service Publication, 772.

Raoult, D., \& Roux, V. (1997). Rickettsioses as paradigms of new or emerging infectious diseases. Clinical Microbiology Reviews, 10(4), 694-719. doi:10.1128/CMR.10.4.694-719.1997

Reysenbach, A., Giver, L. J., Wickham, G. S., \& Pace, N. R. (1992). Differential amplification of rRNA genes by polymerase chain reaction. Applied and Environmental Microbiology, 58, 3417-3418.

Ringo, A. E., Adjou Moumouni, P. F., Lee, S. H., Liu, M., Khamis, Y. H., Gao, Y., ... Xuan, X. (2018). Molecular detection and characterization of tick-borne protozoan and rickettsial pathogens 
isolated from cattle on Pemba Island, Tanzania. Ticks and Tick-Borne Diseases, 9(6), 1437-1445. doi:10.1016/j.ttbdis.2018.06.014

Roux, V., \& Raoult, D. (2000). Phylogenetic analysis of members of the genus Rickettsia using the gene encoding the outer membrane protein rOmpB (ompB). International Journal of Systematic and Evolutionary Microbiology, 50, 1449-1455. doi : 10.1099/00207713-50-4-1449

Rutherford, J. S., Macaluso, K. R., Smith, N., Zaki, S. R., Paddock, C. D., Davis, J. . Rosenberg, R. (2004). Fatal spotted fever. Emerging Infectious Diseases, 10, 910-913. doi : 10.3201/eid1005.030537

Sang, R., Lutomiah, J., Koka, H., Makio, A., Chepkorir, E., Ochieng, C...Schnabel, D.(2011). Crimeancongo hemorrhagic fever virus in hyalommid ticks, northeastern Kenya. Emerging Infectious Diseases, 17, 1502-1505. doi :10.3201/eid1708.102064

Sang, R., Onyango, C., Gachoya, J., Mabinda, E., Konongoi, S., Ofula, V...Miller, B.(2006). Tickborne arbovirus surveillance in market livestock, Nairobi, Kenya. Emerging Infectious Diseases, 12, 10741080. doi:10.3201/eid1207.060253

Sergeant, E. S. G. (2018). Epitools Epidemiological Calculators. Ausvet. Available at: http://epitools.ausvet.com.au.

Simpson, D. I. H., Knight E.M, Courtois. G, Williams M. C, Weinbren M.P, Kibukamusoke J.W. (1967). Congo virus: a hitherto undescribed virus occurring in Africa. Part I. Human isolations-clinical notes. East African Medical Journal, 44, 87-92.

Spengler, J. R., Bergeron, E., \& Rollin, P. E. (2016). Seroepidemiological studies of Crimean-Congo hemorrhagic fever virus in domestic and wild animals. PLoS Neglected Tropical Diseases, 10, 128. doi:10.1371/journal.pntd.0004210

Teshale, S., Geysen, D., Ameni, G., Asfaw, Y., \& Berkvens, D. (2015). Improved molecular detection of Ehrlichia and Anaplasmaspecies applied to Amblyomma ticks collected from cattle and sheep in Ethiopia. Ticks and Tick-Borne Diseases, 6(1), 1-7.doi:10.1016/j.ttbdis.2014.04.023

Villinger, J., Mbaya, M. K., Ouso, D., Kipanga, P. N., Lutomiah,m J., Masiga, D.K. (2017). Arbovirus and insect-specific virus discovery in Kenya by novel six genera multiplex high-resolution melting analysis. Molecular Ecology Resources, 17(3), 466-480. doi:10.1111/1755-0998.12584

Walker, A. R., Bouattour, A., Camicas, J-L., Estrada-Pena, A., Horak I.G., Latif A.A...Preston, P.M. (2004). Ticks of domestic animals in the Mediterranean region: a guide to identification of species. University of Zaragoza, Zaragoza, Spain.

Wesonga, F. D., Kitala, P. M., Gathuma, J. M., Njenga, M. J., \& Ngumi, P. N. (2010). An assessment of tick-borne diseases constraints to livestock production in a smallholder livestock production system in Machakos District, Kenya. Livestock Research for Rural Development, 22(6), 111.

Williams, C. J., Moffitt, C. M. (2001). A critique of methods of sampling and reporting pathogens in populations of fish. Journal of Aquatic Animal Health, 13(4), 300-309. doi:10.1577/15488667(2001)013<0300:ACOMOS > 2.0.CO;2

Woolhouse, M. E. J., Thumbi, S. M., Jennings, A., Chase-Topping, M., Callaby, R., Kiara, H., .. Toye, P. G. (2015). Co-infections determine patterns of mortality in a population exposed to parasite infection. Science Advances, 1(2). doi:10.1126/sciadv.1400026

WHO (2018). Weekly bulletin on outbreaks and other emergencies. Week 26: June 2018. World Health Orgaisation. https://www.afro.who.int/health-topics/disease-outbreaks/outbreaks-and-other-emergenciesupdates

Zhong, J., Jasinskas, A., \& Barbour, A. G. (2007). Antibiotic treatment of the tick vector Amblyomma americanum reduced reproductive fitness. PLoS ONE, 2(5), e405. doi:10.1371/journal.pone.0000405 
Tables

Table 1: Comparison of molecular and morphological identification of ticks

\begin{tabular}{|c|c|c|c|c|c|}
\hline Sample I.D & $\begin{array}{l}\text { Morphological } \\
\text { I.D }\end{array}$ & $\begin{array}{l}\text { 16S rRNA (\% } \\
\text { homology, } \\
\text { GenBank } \\
\text { accession) }\end{array}$ & $\begin{array}{l}\text { ITS2 }(\% \\
\text { homology, } \\
\text { GenBank } \\
\text { accession) }\end{array}$ & $\begin{array}{l}\text { CO1 ( } \% \\
\text { homology, } \\
\text { GenBank } \\
\text { accession) }\end{array}$ & $\begin{array}{l}\text { Consensus ID } \\
\text { (GenBank } \\
\text { accessions) }\end{array}$ \\
\hline $\mathrm{T} 15$ & $\begin{array}{l}\text { Rhipicephalus } \\
\text { sp. }\end{array}$ & $\begin{array}{l}\text { Rh. } \\
\text { decoloratus } \\
(100, \\
\text { EU918193) }\end{array}$ & $\begin{array}{l}\text { Boophilus } \\
\text { decoloratus } \\
(96.7, \text { U97716) }\end{array}$ & - & $\begin{array}{l}\text { Rh. } \\
\text { decoloratus } \\
\text { (16S: } \\
\text { MN266914; } \\
\text { ITS2: } \\
\text { MN266918) }\end{array}$ \\
\hline T16 & $\begin{array}{l}\text { Rh. } \\
\text { appendiculatus }\end{array}$ & $\begin{array}{l}\text { Rh. } \\
\text { appendiculatus } \\
(99.35, \\
\text { KC503257) }\end{array}$ & $\begin{array}{l}\text { Rh. } \\
\text { appendiculatus } \\
(99.8, \text { KX276951 } \\
)\end{array}$ & $\begin{array}{l}\text { Rh. } \\
\text { appendiculatus } \\
(100, \text { KC503257) }\end{array}$ & $\begin{array}{l}\text { Rh. } \\
\text { appendiculatus } \\
\text { (16S: MN266911; } \\
\text { ITS2: } \\
\text { MN266949; } \\
\text { CO1: } \\
\text { MN294736) }\end{array}$ \\
\hline T34 & $\begin{array}{l}\text { Rhipicephalus } \\
\text { sp. }\end{array}$ & $\begin{array}{l}\text { Rh. microplus } \\
(99.2, \\
\text { MH513311) }\end{array}$ & $\begin{array}{l}\text { Rh. microplus } \\
(99.6, \\
\text { KC503265) }\end{array}$ & $\begin{array}{l}\text { Rh. microplus } \\
(100, \\
\text { KY678120) }\end{array}$ & $\begin{array}{l}\text { Rh. microplus } \\
\text { (16S: } \\
\text { MN264523; } \\
\text { ITS2: } \\
\text { MN266952; } \\
\text { CO1: } \\
\text { MN294738) }\end{array}$ \\
\hline T50 & $\begin{array}{l}\text { Rhipicephalus } \\
\text { sp. }\end{array}$ & $\begin{array}{l}\text { Rh. microplus } \\
(99.3 \\
\text { KY020993) }\end{array}$ & $\begin{array}{l}\text { Rh. microplus } \\
(99.6, \\
\text { MG721035) }\end{array}$ & $\begin{array}{l}\text { Rh. microplus } \\
(100, \\
\text { KY678120) }\end{array}$ & $\begin{array}{l}\text { Rh. microplus } \\
\text { (16S: } \\
\text { MN264524; } \\
\text { ITS2: } \\
\text { MN266953; } \\
\text { CO1: } \\
\text { MN294739) }\end{array}$ \\
\hline T62 & $\begin{array}{l}\text { Rhipicephalus } \\
\text { sp. }\end{array}$ & $\begin{array}{l}\text { Rh. } \\
\text { decoloratus } \\
(100, \\
\text { EU918193) }\end{array}$ & $\begin{array}{l}\text { Boophilus } \\
\text { decoloratus } \\
(96.7, \text { U97716) }\end{array}$ & - & $\begin{array}{l}\text { Rh. } \\
\text { decoloratus } \\
\text { (16S: } \\
\text { MN266915; } \\
\text { ITS2: } \\
\text { MN266919) }\end{array}$ \\
\hline T63 & $\begin{array}{l}\text { Rhipicephalus } \\
\text { sp. nymph }\end{array}$ & $\begin{array}{l}\text { Rh. } \\
\text { appendiculatus } \\
(99.35, \\
\text { KC503257) }\end{array}$ & $\begin{array}{l}\text { Rh. } \\
\text { appendiculatus } \\
(99.35, \\
\text { KC503257) }\end{array}$ & $\begin{array}{l}\text { Rh. } \\
\text { appendiculatus } \\
(99.9, \\
\text { KC503257) }\end{array}$ & $\begin{array}{l}\text { Rh. } \\
\text { appendiculatus } \\
\text { (16S: } \\
\text { MN266912; } \\
\text { ITS2: } \\
\text { MN266950; } \\
\text { CO1: } \\
\text { MN294737) }\end{array}$ \\
\hline T105 & $\begin{array}{l}\text { Rh. } \\
\text { decoloratus }\end{array}$ & $\begin{array}{l}\text { Rh. microplus } \\
\text { (99.1, } \\
\text { MH513311) }\end{array}$ & - & - & $\begin{array}{l}\text { Rh. microplus } \\
\text { (16S: } \\
\text { MN264525) }\end{array}$ \\
\hline
\end{tabular}




\begin{tabular}{|c|c|c|c|c|c|}
\hline Sample I.D & $\begin{array}{l}\text { Morphological } \\
\text { I.D }\end{array}$ & $\begin{array}{l}\text { 16S rRNA (\% } \\
\text { homology, } \\
\text { GenBank } \\
\text { accession) }\end{array}$ & $\begin{array}{l}\text { ITS2 (\% } \\
\text { homology, } \\
\text { GenBank } \\
\text { accession) }\end{array}$ & $\begin{array}{l}\text { CO1 ( } \% \\
\text { homology, } \\
\text { GenBank } \\
\text { accession) }\end{array}$ & $\begin{array}{l}\text { Consensus ID } \\
\text { (GenBank } \\
\text { accessions) }\end{array}$ \\
\hline T134 & $\begin{array}{l}\text { Rh. } \\
\text { decoloratus }\end{array}$ & $\begin{array}{l}\text { Rh. } \\
\text { decoloratus } \\
(100, \\
\text { EU918193) }\end{array}$ & $\begin{array}{l}\text { Boophilus } \\
\text { decoloratus } \\
(96.7, \text { U97716) }\end{array}$ & - & $\begin{array}{l}\text { Rh. } \\
\text { decoloratus } \\
\text { (16S: } \\
\text { MN266916; } \\
\text { ITS2: } \\
\text { MN266921) }\end{array}$ \\
\hline T192 & $\begin{array}{l}\text { Haemaphysalis } \\
\text { sp. }\end{array}$ & $\begin{array}{l}\text { Ha. elliptica } \\
(95.6, \text { HM068961) }\end{array}$ & $\begin{array}{l}\text { Ha. erinacei } \\
(88, \\
\text { KU364288) }\end{array}$ & $\begin{array}{l}\text { Ha. erinacei } \\
(99.3, \\
\text { KU880573) }\end{array}$ & $\begin{array}{l}\text { Haemaphysalis } \\
\text { sp. (16S: } \\
\text { MN264214; } \\
\text { ITS2: } \\
\text { MN266944;CO1: } \\
\text { MN294735) }\end{array}$ \\
\hline T199 & $\begin{array}{l}\text { Am. } \\
\text { variegatum }\end{array}$ & $\begin{array}{l}\text { Am. } \\
\text { variegatum } \\
(99.3, \text { L34312) }\end{array}$ & $\begin{array}{l}\text { Am. } \\
\text { variegatum } \\
(100, \\
\text { HQ856803) }\end{array}$ & - & $\begin{array}{l}\text { Am. } \\
\text { variegatum } \\
\text { (16S: } \\
\text { MN266929; } \\
\text { ITS2: } \\
\text { MN401349) }\end{array}$ \\
\hline T218 & $\begin{array}{l}\text { Rhipicephalus } \\
\text { sp. nymph }\end{array}$ & $\begin{array}{l}\text { Rh. } \\
\text { appendiculatus } \\
(99.51, \\
\text { KC503257) }\end{array}$ & $\begin{array}{l}\text { Rh. } \\
\text { appendiculatus } \\
(99.73, \\
\text { KY457500) }\end{array}$ & - & $\begin{array}{l}\text { Rh. } \\
\text { appendiculatus } \\
\text { (16S: } \\
\text { MN266913; } \\
\text { ITS2: } \\
\text { MN266951) }\end{array}$ \\
\hline $\mathrm{T} 222$ & Am. gemma & - & $\begin{array}{l}\text { Am. hebraeum } \\
(99.65, \\
\text { KY457490) }\end{array}$ & - & $\begin{array}{l}\text { Am. gemma } \\
\text { (ITS2: } \\
\text { MN401350) }\end{array}$ \\
\hline T311 & $\begin{array}{l}\text { Amblyomma } \\
\text { sp. nymph }\end{array}$ & $\begin{array}{l}\text { Am. } \\
\text { variegatum } \\
(99.3, \text { L34312) }\end{array}$ & $\begin{array}{l}\text { Am. } \\
\text { variegatum } \\
(100, \\
\text { HQ856803) }\end{array}$ & - & $\begin{array}{l}\text { Am. } \\
\text { variegatum } \\
\text { (16S: } \\
\text { MN266930; } \\
\text { ITS2: } \\
\text { MN401351) }\end{array}$ \\
\hline T321 & $\begin{array}{l}\text { Rhipicephalus } \\
\text { sp. }\end{array}$ & $\begin{array}{l}\text { Rh. simus } \\
(96.28, \\
\text { KJ613641) }\end{array}$ & - & - & $\begin{array}{l}\text { Rhipicephalus } \\
\text { sp. (16S: } \\
\text { MN266945) }\end{array}$ \\
\hline
\end{tabular}

Table 2: Vector-borne pathogens detected in pools of ticks and lice from livestock markets and slaughterhouses

\begin{tabular}{lllllll}
\hline Pathogen & Rhipicephalus spp. & Rh. decoloratus & Rh. appendiculatus & Rh. evertsi & Rhipicephalus sp. & Amblyomm \\
\hline Total pools & $215++$ & 108 & 33 & 18 & 54 & 99 \\
A. marginale & $6(1.88 \%)$ & $4(2.44 \%)+$ & - & - & $2(2.90 \%)$ & - \\
A. ovis & $6(1.88 \%)$ & $2(1.21 \%)$ & - & $1(4.17 \%)$ & $3(4.35 \%)$ & - \\
A. platys & $10(3.15 \%)$ & $5(3.05 \%)$ & $3(5.51 \%)$ & - & $2(2.92 \%)$ & - \\
B. bigemina & $2(0.63 \%)$ & $1(0.61 \%)$ & $1(1.84 \%)$ & - & - & $1(0.75 \%)$
\end{tabular}




\begin{tabular}{lllllll}
\hline Pathogen & Rhipicephalus spp. & Rh. decoloratus & Rh. appendiculatus & Rh. evertsi & Rhipicephalus sp. & Amblyomm \\
\hline B. caballi & - & - & - & - & - & $8(6.14 \%)$ \\
H. canis & $1(0.31 \%)$ & $1(0.61 \%)$ & - & - & - & - \\
R. africae & $8(2.52 \%)$ & $3(1.83 \%)$ & $1(1.82 \%)$ & - & $4(5.89 \%)$ & $83(77.45 \%)$ \\
T. mutans & $18(5.64 \%)$ & $12(7.32 \%)$ & - & - & $6(8.83 \%)$ & $1(0.75 \%)$ \\
T. parva & $1(0.31 \%)$ & - & - & - & $1(1.45 \%)$ & - \\
T. taurotragi & $6(1.88 \%)$ & $2(1.21 \%)$ & $1(1.80 \%)$ & - & $3(4.38 \%)$ & - \\
T. velifera & $1(0.31 \%)$ & - & - & - & $1(1.45 \%)$ & $2(1.49 \%)$ \\
CCHF virus & $2(0.62 \%)$ & $1(0.61 \%)$ & - & - & $1(1.45 \%)$ & - \\
\hline
\end{tabular}

+Estimated individual-level prevalence percentages (in brackets) were calculated based on the size of each pool tested

++ These totals also include Rh. microplus, Haemaphysalis sp., and Ct. felis pools that were not positive for any pathogens

Figure legends

Figure 1. Map of the three neighbouring counties of Busia, Bungoma, and Kakamega showing the livestock markets and slaughterhouses from which arthropod samples were collected .

Figure 2. Melt rate profiles. (A) CCHF virus RdRp amplicons, (B) Theileria/Babesia 18S rRNA amplicons, (C) Anaplasma16SrRNA amplicons, and (D) Rickettsia/Coxiella 16S rRNA amplicons. PC: positive control. Ra: Rh. appendiculatus . Rd:Rh. decoloratus .

Figure 3. Maximum likelihood phylogeny of Crimean-Congo haemorrhagic fever virus strains inferred from 34 aligned 434-nt segments of the L-segment (RdRp gene). GenBank accession numbers and country of origin are indicated for each sequence. Accession numbers for sequences from this from this study are in bold. Isolation sources in applicable sequences are also highlighted. Bootstrap values at the major nodes are of percentage agreement among 1,000 replicates. The branch length scale represents substitutions per site. The gaps indicated in the branches to the Nairobi sheep disease outgroup represent 0.8 substitutions per site. The sequences from this study fall into African genotype II as indicated by the vertical bars.

Figure 4. Maximum likelihood phylogeny of apicomplexan protozoa inferred from 32 aligned 502-nt segments of the 18S rRNA gene. GenBank accession numbers and isolation sources are indicated for each sequence. Accession numbers for sequences from this study are in bold. Bootstrap values at the major nodes are of percentage agreement among 1,000 replicates. The branch length scale represents substitutions per site.

Figure 5. Maximum likelihood phylogeny of tick-associated Coxiella endosymbionts inferred from 33 aligned 279-nt segments of the 16S rRNA gene. GenBank accession numbers and tick species of origin are indicated for each sequence. Accession numbers for sequences from this study are in bold Bootstrap values at the major nodes are of percentage agreement among 1,000 replicates. The branch length scale represents substitutions per site. The gaps indicated in the branches to the L. pneumophila outgroup represent 0.12 substitutions per site. Sequences from this study and those from GenBank fall into three genotypes: $\mathbf{A}=$ Coxiella burnetii $\mathbf{B}=$ Coxiella endosymbionts of Amblyomma spp. ticks; $\mathbf{C}=$ Coxiella endosymbionts of Rhipicephalus spp. ticks; $\mathbf{D}=$ Coxiella endosymbionts of Dermacentor andAmblyomma spp. ticks.

\section{Supplementary figure legends}

Supplementary Figure 1. Photographs of representative specimens of vectors collected from livestock at livestock markets and slaughterhouses: A. Am. gemma female; B. Am. gemma male; 
C. Amblyomma sp. nymph; D. Am variegatum female; E.Am variegatum male; F. Haemaphysalis sp.; G.Rhipicephalus evertsi female and male; H. Rh. evertsimale; I. Rh. appendiculatus male; J. Rh. appendiculatusfemale; K. Rh. decoloratus; L. Haematopinus suis; M. Ctenocephalides felis.

Supplementary Figure 2. Partial ompB gene sequences of Rickettsia africae obtained from this study aligned with GenBank reference sequences. Accession numbers of sequences from this study are in bold. Note the deletion mutation of a 4-base pair motif and several base substitutions in the sequences. Red $=$ Adenine; Blue $=$ Cytosine; Green $=$ Thymine; Yellow $=$ Guanine; Grey $=$ consensus with $R$. africae reference sequence.

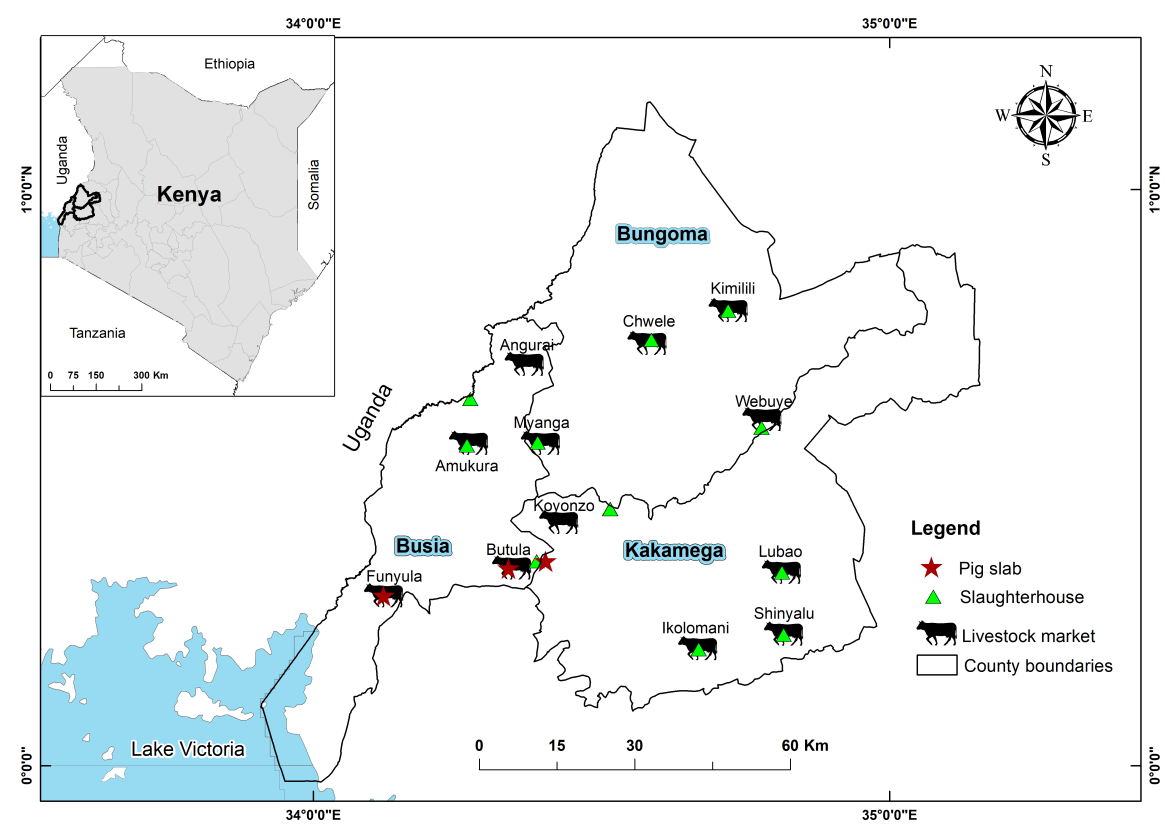


figures/Fig2/Fig2-eps-converted-to.pdf 
figures/Fig3/Fig3-eps-converted-to.pdf 
figures/Fig4/Fig4-eps-converted-to.pdf 
figures/Fig5/Fig5-eps-converted-to.pdf 